\title{
基底細胞癌の深部浸潤
}

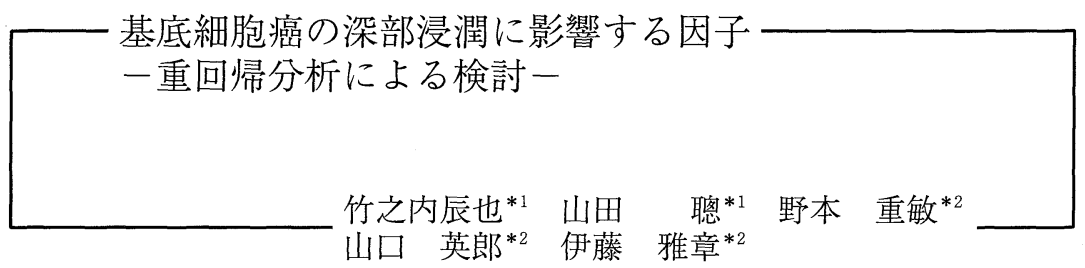

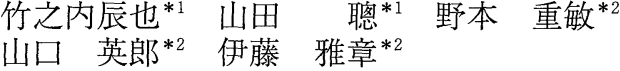

\section{Factors influencing deep invasion of basal cell carcinoma multiple linear regression analysis}

Tatsuya TAKENOUCHI ${ }^{* 1}$, Satoshi YAMADA *1, Shigetoshi NOMOTO *2, Hideo YAMAGUCHI ${ }^{* 2}$, Masaaki ITO *2

*1 Division of Dermatology, Niigata Cancer Center Hospital

*2 Department of Dermatology, Niigata University School of Medicine

Basal cell carcinoma $(\mathrm{BCC})$ usually grows slowly, increasing in size and depth of invasion over months to years. It is important prior to surgery to predict aggressive behavior of BCC, especially its deeper extension. In 216 primary BCCs treated with surgical excision, maximum vertical diameter, designated as "invasion index," from the surrounding skin surface to the bottom of the tumor was measured. As predictive factors, age, sex, duration, anatomical location, tumor horizontal diameter, histologic subtypes, and ulceration were listed. Multiple linear regression analysis, which was performed on the seven factors related to the invasion index, showed significant strength of influence of male sex, larger tumor horizontal diameter, and aggressive histologic subtypes (infiltrative, morpheic, and micronodular). When treating $\mathrm{BCC}$ having the three predictive factors, clinicians should keep in mind its potential for deeper invasion. [Skin Cancer (Japan) $2000 ; 15$ : 138-142]

Key words : Basal cell carcinoma, Depth of invasion, Multiple linear regression analysis

\section{はじめに}

基底細胞癌（BCC）の手術治療にあたって は，大半が顔面に発生する ${ }^{1)}$ という特性から， 水平方向のみならず深部の切除範囲の設定に苦

*1 新潟県立がんセンター皮膚科

*2 新潟大学皮膚科学教室
慮することが多い。その意味で，術前の情報か ら組織学的な深部浸潤を予測することは手術計 画を立てる上で重要である。我々は以前に同様 の主旨で, BCCの臨床因子と深部浸潤レベルと の関係について単変量解析で検討した ${ }^{2)}$ 。今回 は対象症例を増やすとともに，個々の因子が単 独で深部浸潤に及ぼす影響の強さを評価する目 的で，重回帰分析による検討を行った。 


\section{対象および方法}

新潟県立がんセンターで 1989～1998 年に, 新潟大学で 1983 ～ 1997 年に経験した BCC の うち，初回治療として全切除された症例は 249 例であり，組織学的に superficial BCC と診断さ れた 33 例を除外し，残りの 216 例を今回の研 究対象とした。

深部浸潤径の計測（図 1): 切除標本の HE 染 色切片上で，腫瘍周囲の健常部の皮表面から腫 瘍巣最深部までの垂直距離をocular micrometer で計測した。1つの標本で複数の組 織切片がある場合には，それぞれの切片につい て深部浸潤径を計測し，最も大きな值を採用し た。

重回帰分析：計測した深部浸潤径を従属变数 とし，それを説明するための独立変数として以
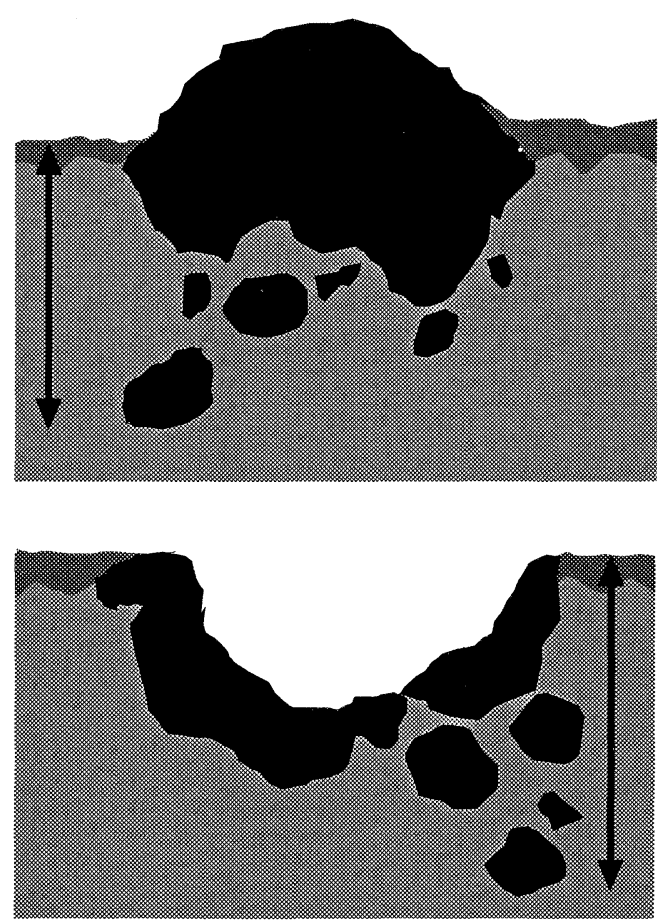

図 1. 深部浸潤径の計測 腫瘍周辺部の皮表面から腫瘍最深部までの垂 直距離を ocular micrometer で計測し，深部 浸潤径（両矢印）とした
下の 7 因子を設定した（表 1 ）。(1)年齢は，連続 変数として取り入れた。(2)性別は，男 $=1$, 女 =0のダミー変数とした。(3)罹病期間について は，問診上曖昧な年数の場合が多いため，ほぼ 中央值となる 4 年を境に， 4 年超と 4 年以下の 2 群に分け，それぞれ 1 と 0 の変数とした。(4) 発生部位は, 眼瞼, 鼻, 口唇 $=1$, それ以外の 部位 $=0$ とした。(5)腫瘍径は，カルテに記載さ れた術前診察時の計測值を採用し，ミリメー ター表示で連続変数のまま取り入れた。(6)組織 型は, Sextonらによる 5 型分類 ${ }^{3)}$ の内, superficial type は除外してあるため, infiltrative, morpheic, micronodular $の 3$ 型= 1 , nodular type $=0$ とした。同一の症例で 2 種 以上の組織型が混在している場合には，主体と なっている組織型を採用した。(7)潰瘍形成は, 臨床的に潰瘍化しているか，痂皮を付着してい るものを潰瘍形成あり=1をあてはめ，潰瘍な し=0 とした。これら 7 因子の独立変数を共変 量とし，深部浸潤径に対する影響力の強さを評 価する目的で重回帰分析を施行した。

統計学的処理には StatView 5.0 J (Abacus Concepts, Inc.）を用い, 有意差検定における危 険率は $5 \%$ とした。

表 1. 独立変数とした因子

\begin{tabular}{|c|c|c|}
\hline \multirow{2}{*}{$\begin{array}{l}\text { 年齢 } \\
\text { 性別 }\end{array}$} & \multicolumn{2}{|c|}{ 平均67.1歳 標準偏差 13.0} \\
\hline & 男 & 107例 \\
\hline & 女 & 109例 \\
\hline \multirow[t]{2}{*}{ 罹病期間 } & $>4$ 年 & 107例 \\
\hline & $\leqq 4$ 年 & 109例 \\
\hline \multirow[t]{2}{*}{ 部位 } & 眼瞼・鼻・口唇 & 115 例 \\
\hline & 上記以外 & 101 例 \\
\hline 腫瘍径 & 平均 $13.2 \mathrm{~mm}$ 標 & \\
\hline \multirow[t]{4}{*}{ 組織型 } & Infiltrative & \\
\hline & Morpheic & 81 例 \\
\hline & Micronodular & \\
\hline & Nodular & 135 例 \\
\hline \multirow[t]{2}{*}{ 潰瘍形成 } & あり & 119 例 \\
\hline & なし & 97例 \\
\hline
\end{tabular}


表 2．重回帰分析の結果

性別, 腫瘍径, 組織型の 3 因子が, 基底細胞 癌の深部浸潤径に対して有意な影響を示した

\begin{tabular}{c|cl}
\hline 独立変数 & 標準偏回帰係数 & \multicolumn{1}{c}{$\mathrm{p}$ 値 } \\
\hline 年齢 & 0.110 & 0.0932 \\
性別 & 0.238 & $0.0003^{* * *}$ \\
罹病期間 & -0.023 & 0.7205 \\
部位 & 0.108 & 0.1139 \\
腫瘍径 & 0.254 & $0.0006^{* * *}$ \\
組織型 & 0.207 & $0.0022^{* *}$ \\
潰瘍形成 & -0.070 & 0.2941 \\
\hline
\end{tabular}

結＼cjkstart果

重回帰分析の結果，7因子の中で深部浸潤径 に有意に影響するのは, 性別 $(\mathrm{p}=0.0003)$, 最大 径 $(p=0.0006)$, 組織型 $(p=0.0022)$ の 3 因子 であった。それぞれの因子の標準偏回帰係数 は, $0.238,0.254,0.207$ あった。年歯 $(p=0.0932)$, 罹 病期間 $(p=0.7205)$, 部 位 $(\mathrm{p}=0.1139)$ および潰瘍形成 $(\mathrm{p}=0.2941)$ につい ては，深部浸潤径に対する有意な影響は認めな かった。回帰モデルの重相関係数（R）は 0.42 , 決定係数 $\left(\mathrm{R}^{2}\right)$ は 0.18 であった（表 2$) 。$

\section{考察}

皮膚腫瘍において深部浸潤の程度を組織学的 に評価するには, 悪性黒色腫の Breslow's thicknessのように腫瘍巣の垂直径をミリメー ター単位で計測する ${ }^{4)}$ か, Clark's levelのよう に深達度を解剖学的な層で表現する ${ }^{5)}$ のが合理 的である。我々は以前, BCC の深部浸潤度を真 皮浅層〜深層〜皮下組織にかけて 4 段階で評価 し，臨床因子との関連について検討した ${ }^{2)}$ が, BCC の大半が発生する顔面に打いては真皮の 厚さや表情筋の分布など, 部位による解剖学的 構造の偏りが大きいため, その深部浸潤の評価 に再現性, 客観性を欠くことが問題点として 残った。そこで今回の検討では, 腫瘍周辺の健
常部皮表面から腫瘍最深部までの垂直距離を絶 対值として計測し，客観性を持った深部浸潤の 指標とした。

今回の重回帰分析の結果から，独立変数とし た 7 因子の中で，深部浸潤径への影響力が最も 強かったのは腫瘍径であった。腫瘍径が大きい 程, 水平方向の subclinical extension (SE) \& 大きいことは過去に報告されている(6) が，深 部方向についての検討はなされていない。 Superficial type を除けば, BCC がその増殖に 伴って水平方向のみでなく深部方向へも進展し ていくのは自然なことであり, 今回の結果から も腫瘍径は深部浸潤を予測する上において重要 な独立した因子であることが示された。

性別については，男性の方が深部浸潤径が大 きいという結果であった。BCCの術後再発率に 関する検討で, 男性の方が再発率が高いとする 報告 ${ }^{8)}$ もあり，その理由として女性の方が早期 に受診する例が多いためとされている が，今 回の検討では罹病期間も共変量に組み入れてい るため受診時期についての bias は除外できる。 その他 1 つの可能性としてあげられるのは, 男 性における髭の存在である。硬毛組織の毛球部 は通常皮下脂肪織内に位置するため, 毛包に 沿って浸潤したBCC (図 2 ) は容易に皮下へ浸 潤すると考えられる。大半の BCC が顔面に発 生する事実 ${ }^{1)}$ と考え合わせると，このような皮 膚の構造の性差が BCC の深部浸潤度の差とし て表れているのかもしれない。

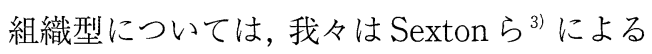
5 型分類を採用している ${ }^{10)}$ が, superficial type は増殖様式が特殊であり, 今回の研究の主旨か らは外れるため除外した。 Infiltrative, morpheic, micronodularの 3 型については, そ の $\mathrm{SE}$ のきさと再発率の高さゆえに aggressive subtype と称される ${ }^{11)}$ が, 今回の結 果からは, 深部方向についてもその 3 型は nodular type に比べて浸潤が深いことが示され た。BCCの組織型と深部浸潤との関連について は, Mohs surgeryにおいて完全切除までに要し 


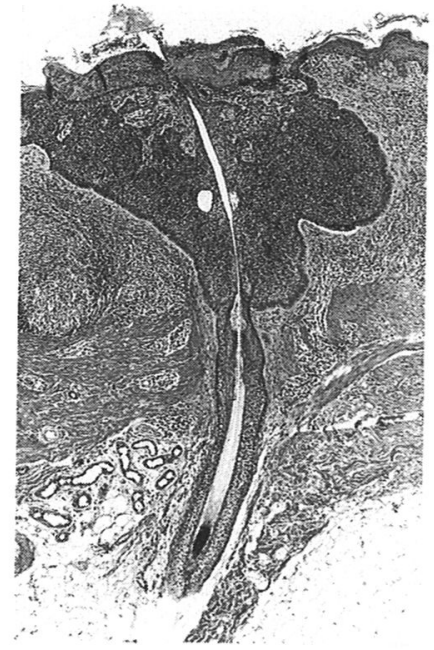

図 2，基底細胞癌の毛包に沿った浸潤像

たステージ数や組織学的な深達度での評価か ら, 我々の結果と同様の報告がされてい る ${ }^{12)}$ 15)。

発生部位に関しては, 深部浸潤径に対して有 意な影響がないという結果となった。眼瞼, 鼻, 口唇のいわゆる midface は BCC の再発率が高 いとする報告が多く，その主な理由の 1 つとし て embryonal fusion plane の存在があげられて いる ${ }^{16) 17)}$ 。これは顔面の発生段階での突起同士の 癒合面が残存し，それに沿った形で腫瘍が深部 方向に容易に浸潤する（iceberg phenomenon） という仮説である。確かに概念としては理解し やすいが，成人の顔面に扔いてどの部位が fusion plane に相当するのかを正確に特定する ことは不可能であり, 自験例でその付近に発生 したと思われる症例につき丹念に組織標本を観 察したが，それと認識できるような結合織構造 は全く認めなかった。fusion plane の存在だけ でなく定義自体にも疑問を呈した報告もあ る ${ }^{18)}$ 。

BCC の腫瘍表面の潰瘍形成は aggressive growthの指標とする報告があり ${ }^{19)}$, 我々も以前 に，潰瘍形成の有無により組織学的な浸潤レベ ルに有意差がみられたことを報告した ${ }^{2)}$ が，そ れは単変量解析であるため, 他の因子の影響に
ついては考慮していない。今回の多変量解析の 結果からは, 潰瘍形成は深部浸潤径に独立して 影響する因子とは認められなかった。

臨床医が BCC を実際に取り扱う際には，そ の臨床像や事前の生検組織像から水平方向のみ ならず深部方向の SEをある程度予想して切除 範囲を決めるのが一般的であろう。Mohs surgery ${ }^{20)}$ は腫瘍切除と即時断端確認を繰り返 す究極の手技ではあるが，その煩雑さと人員確 保などが問題点となる。我々は, 顔面の BCCに おいては，切除と再建を二期に分けた手術を励 行している ${ }^{21)}$ が，全例に施行するわけではな く, 症例の選択という点に扔いても今回の検討 の結果は重要となる。腫瘍径が大きい, もしく は男性,もしくは infiltrative, morpheic, micronodular type の症例についてはより深部 への浸潤が予想されるため，それを考慮に入れ た上での手術計画や術後の follow up が必要で ある。

\section{文献}

1）石原和之：基底細胞癌. 全国アンケートの集計と 説明. Skin Cancer, 9:80-83, 1994.

2）竹之内辰也, 勝海薰, 山田聰, 他 : 基底細胞癌に 抢ける深部浸潤の予測因子. Skin Cancer, 13： 163-166, 1998.

3) Sexton, M., Jones, D.B., Maloney, M.E. : Histologic pattern analysis of basal cell carcinoma : Study of a series of 1039 consecutive neoplasms. J. Am. Acad. Dermatol., 23 : 1118-1126, 1990.

4) Breslow, A.: Thickness, cross-sectional areas and depth of invasion in the prognosis of cutaneous melanoma. Ann. Surg., 172 : 902-908, 1970.

5) Clark, W.H., From, L., Bernardino, E.A., et al. : The histogenesis and biologic behavior of primary human malignant melanoma of the skin. Cancer, Res., 29: 705-726, 1969.

6) Burg, G., Hirsch, R.D., Konz, B., et al. : Histographic surgery : Accuracy of visual assessment of the margins of basal-cell epithelioma. J. of Derm. Surg., 1:21-24, 1975.

7) Wolf, D.J., Zitelli, J.A. : Surgical margins for basal cell carcinoma. Arch. Dermatol., 123 : 340-344, 
1987.

8) Rigel, D.S., Robins, P., Friedman, R.J. : Predicting recurrence of basal-cell carcinomas treated by microscopically controlled excision. J. Dermatol. Surg. Oncol, 7 : 807-810, 1981.

9) Boeta-Angeles, L., Bennett, R.G. : Cutaneous oncology. Miller, S.J., Maloney, M.E. eds, Blackwell, U.K., 1998, pp646-656.

10）竹之内辰也, 山田聰, 野本重敏, 他: 基底細胞癌 の組織型と深部浸潤. 臨皮, 54:481-484, 2000.

11) Maloney, M.E., Miller, S.J. : Cutaneous oncology. Miller, S.J., Maloney, M.E. eds, Blackwell, U.K., 1998, pp609-613.

12) Salasche, S.J., Amonette, R.A. : Morpheaform basal-cell epitheliomas : A study of subclinical extensions in a series of 51 cases. J. Dermatol. Surg. Oncol., $7: 387-394,1981$.

13) Hendrix, J.D., Parlette, H.L. : Duplicitous growth of infiltrative basal cell carcinoma : Analysis of clinically undetected tumor extent in a paired case-control study. Dermatol. Surg., 22 : 535-539, 1996.

14) Hendrix, J.D., Parlette, H.L. : Micronodular basal cell carcinoma : A deceptive histologic subtype with frequent clinically undetected tumor extension. Arch. Dermatol., 132 :295-298, 1996.
15) Orengo, I.F., Salasche, S.J., Fewkes, J., et al. : Correlation of histologic subtypes of primary basal cell carcinoma and number of Mohs stages required to achieve tumor-free plane. J. Am. Acad. Dermatol., 37:395-397, 1997.

16) Panje, W.R., Ceilley, R.I. : The influence of embryology of the mid-face on the spread of epithelial malignancies. Laryngoscope, 89 : 19141920, 1979.

17 ) Granstrom, G., Aldenborg, F., Jeppsson, P.A. : Influence of embryonal fusion lines for recurrence of basal cell carcinoma in the head and neck. Otolaryngol Head Neck Surg., 85: 76-82, 1986.

18) Wentzell, J.M., Robinson, J.K. : Embryologic fusion planes and the spread of cutaneous carcinoma: A review and reassessment. J. Dermatol. Surg. Oncol., 16: 1000-1007, 1990.

19) Jacobs, G.H., Rippey, J.J., Altini, M. : Prediction of aggressive behavior in basal cell carcinoma. Cancer, 49:533-537, 1982.

20) Mohs, F.E. : Chemosurgery for the microscopically controlled excision of cutaneous cancer. Head Neck Surg., 1:150-163, 1978.

21）山田聰, 竹之内辰也, 野本重敏, 他 : 基底細胞癌 に対する二期的手術の有用性. 皮膚臨床, 41： 2055-2058, 1999. 